\title{
The development of preschoolers' financial literacy in the cooperation of the kindergarten and the family
}

\author{
Natalia Vladimirovna Belinova ${ }^{1 *}$, Irina Borisovna Bicheva $^{1}$, Larisa Vladimirovna \\ Krasilnikova $^{1}$, Tatiana Gennadievna Khanova ${ }^{1}$, Natalya Vyacheslavovna Vyalova $^{1}$, and \\ Zhanna Khasanbekovna Baskaeva ${ }^{2}$ \\ ${ }^{1}$ Minin Nizhny Novgorod State Pedagogical University \\ ${ }^{2}$ North Ossetian State University
}

\begin{abstract}
The article introduces the study of the development of preschoolers' financial and economic literacy in the context of cooperation between the kindergarten and the parents. The authors analyze the relevance and the need to teach children the basics of economics from an early age, it is emphasized that children face and deal with various economic concepts early, and the task of adults is to develop the basis of children's economic thinking. The authors consider the foundations of financial literacy and a successful solution to this task in unity with morallabor education. The article describes the diagnostics, form, and control stages of the experiment in work with parents and children in the development of basic financial and economic literacy. The review of the stages covers the results of the diagnostics, an activity plan with parents and children, the final results of testing the developed approaches. In the content of economic education, the authors include such important tasks as the development of ideas about the professional activity of grown-ups, the family budget, money, advertising, the development of useful skills and habits in everyday life, etc. It is noted that rationally selected methods and means of education make it possible to introduce the child to the world of economics, to master complex financial categories and relations. The authors proved that the development of the elementary financial literacy of children is possible only in the cooperation and close interaction with the family.
\end{abstract}

\section{Introduction}

Children's financial literacy as the basis of economic education is considered as one of the frontier problems of contemporary education. Modern social discourse demands to raise the child as a subject of economic socialization and education. The tendency toward a change in economic priorities has been observed clearly in the society: financial benefits being significantly important for a person sometimes to the detriment of moral values (Bicheva,

\footnotetext{
* Corresponding author: belinova@,mail.ru
} 
Nikolaeva \& al. 2019). In this regard the importance of children's financial literacy is determined by many factors, among which should be noted:

- socio-economic crisis of social formation, interfering in the financial relations of the younger generation (Vaganova, Lapshova \& al.2020);

- public differentiation of the population with high and low wages;

- significant changes in education: positive (variability of schools, the latest technological processes in the training of teachers) and negative (increase in optional educational services prices);

- stratification of children's society (in terms of material, educational and other indicators), criminalization in the juvenal sphere, loss of value orientations, and moral vacuum;

- response - protective reactions of children to the process of independent resolution of problem situations associated with the implementation of material and spiritual needs (Anoshina, 2003).

Russian researchers (L.N. Galkina, S.A. Kozlova, E.A. Kurak, A.D. Shatova, A.A. Smolentseva, etc.) as well as foreign scientists (D. Pearl, D. Gulfrey, N. Beverly, etc.) studying the problem of early involvement of children in the economy, have drawn out the necessity to develop a new, modern style of children's thinking to meet the requirements of the time. Before that economic problems were artificially moved away from the child, then modern life realities urgently require the development of children's ideas about the basics of trade, economic, and financial aspects. Research by A.D. Shatova highlights the accelerating pace of economic socialization of modern children: they do not only know but can also correlate economic concepts with the corresponding life situations (Shatova, 2018).

In any vector of upbringing and child development, family plays a very important role. As follows from numerous research works, a kindergarten or a school can fully satisfy the needs of the family when it is an open system, and parents are subjects of interaction with professional staff (Kozyreva, 2020). The family as a partner and active participant in the educational environment starkly changes the interaction between teachers and parents and puts forward the need to develop a system of measures for pedagogical support of positive parenting (Knyshova, Menshikov \& al. 1996).

Financial literacy and the economic education of children is a fairly new direction in the development of children that have not yet been singled out in a separate educational trend. Only separate tasks of economic education are solved in the context of the educational curriculum (Kolesova, Gutsu, \& al. 2020). Accordingly, interaction with parents in this matter is also not built up, which served as the opportunity to carry out work in this direction.

The concept of "economic education" is interpreted differently in pedagogy. In the pedagogical dictionary, economic education is the targeted interaction of educators and pupils, aimed at the gaining of the knowledge, skills and needs, interests, and economic thinking style, corresponding to the nature, principles, and norms of rational management and organization of production, distribution, and consumption (Smirnova, Vaganova, \& al. 2020). V.N. Myasishchev writes that economic education is “the development of a person's specific concept of ideas, good manners, industriousness, communication skills that have become inherent" (Myasishchev, 1993). Considering this problem, L.P. Kurakov points out that "economic upbringing" and "economic education" are two different, but closely interwoven, parts of a single process - economic training (Kurakov, 2010). Zhukova T. argues that economic education is "a directed process of regular influence on a person, his inclusion in various types of economic activity to develop economic thinking, the economic qualities necessary for industrial and economic work and economic relations out of production" (Zhuykova \& Kokukhina, 2016). 
Having analyzed these approaches, we can say that economic education is the development of economic thinking, the mastery of economic knowledge, skills, the development of personal qualities that reflect economically significant moral values. Due to the age characteristics of children, the concept of "economic education" is not entirely applicable in the kindergarten or elementary school in its traditional interpretation (Khanova \& Prokofieva, 2018). I.A. Sasova believes that in preschool age, only the development of the prerequisites for economic education is possible. I.A. Sasova thinks that the economic education of preschoolers is the process of including children in the socioeconomic relations inherent in modern discourse, the education of thinking, behavior, and activities consistent with the economic and moral foundations of society (Sasova, 2019). L.N. Galkina believes that the main tasks of economic education of children are the development of economic skills and the rational organization of labor, knowledge of the laws of the economy and the organization of production, the education of the moral and economic qualities of the individual, the development of reasonable economic needs (Galkina, 2010).

The idea that the basics of economic education are labor education is supported by A.D. Shatova. She considers the assimilation of financial literacy in preschool-age in close unity with moral and labor education, as children should know that money is value, wealth, etc., but they need to learn where they come from (Shatova, 2013). D.S. Chesnouskene analyzes the state of economic education and upbringing of children, outlines the features of the perception of banknotes, their purchasing opportunities. She developed a methodology for introducing children to banknotes, concepts, expensive, cheap, purchasing power of money, depending on their quantity (Prokofieva \& Khanova, 2018). Some studies note that most children do not have a clear idea of the needs and expenses of the family, the work of the parents, the ways of earning and spending money, etc. (Kurbatova, Bicheva \& al., 2020). In the research by A.D. Shatovoy, A.A. Smolentseva, L.N. Galkina the main approaches to the tasks of economic education of children were singled out and it was proved that a stable and continuous economic education must be started precisely from preschool age when children gain primary experience in elementary economic relations.

The process of financial literacy and economic education development of children is inextricably linked with moral and labor education and is an important component of educational work (Vaganova, Rudenko \& al., 2020).

When analyzing the scientific and pedagogical studies related to the economic education of children, attention should be paid to the fact that the family plays a large role in the economic education of children, the child gets the social experience when encountering the concepts of "money", "expensive", "cheap", "salary", "family budget" (Yashkova, Sineva, \& al., 2020). E.A. Burina and A.E. Kudinova note that in most modern families there is a shift in the "psychological center" from pronounced childcentrism "towards ensuring equal opportunities for self-realization of all its members, while parenting ceases to be the only central element of the family system", which inevitably leads to early socialization of children, including in the financial and economic sphere (Burina \& Kudinova, 2020).

So, the economic education of children should be understood as an organized pedagogical activity, which is aimed at establishing an economic attitude to material and spiritual values, the development of elementary economic ideas, knowledge, concepts that contribute to the development of moral and economic qualities of a person. Financial literacy is "the result of the process of financial education, which is defined as the combination of awareness, knowledge, skills and behavioral models necessary for making successful financial decisions and ultimately to achieve financial well-being”. 


\section{Materials and methods}

Based on the relevance of the problem the initiative of the research was set as a study of the opportunities and effectiveness of the interaction and cooperation of the kindergarten with the family in the development of preschoolers' financial literacy.

Research objectives lie as follows: 1) to carry out a theoretical analysis of scientific and pedagogical research and practical experience of kindergartens on the issue of economic education and financial literacy of children; 2) to test the level of financial and economic development of children; 3 ) to develop and test a model of interaction with parents on the economic education of children; 4) analyze the results obtained, conclude the effectiveness of the work done.

The purpose and objectives of the study determined the set of methods:

- theoretical analysis of scientific (psychological, pedagogical) and educational literature; analysis and synthesis of scientific literature on the topic of research;

- empirical, combined in the frame of the diagnostic, formative, and control stages of the experimental - search work, observation, experiment;

- mathematical methods: quantitative data processing: a comparative, graphical, and mathematical analysis.

\section{Results}

The conducted experiment included diagnostic activities aimed at identifying the level of preschoolers' financial literacy and the degree of parental participation in economic education as well as the development of the model of cooperation with the parents

The results of the diagnostics revealed no children well-versed in economic issues in the focus group. 53\% of children have an average level of mastery of financial literacy: they have certain economic knowledge, but they are not always applied in practice, solving problematic situations causes difficulties. A low level of development was revealed in $47 \%$ of children: they are not aware of the financial and economic categories.

Parents taking part in the questionnaire do not pay due attention to the teaching of the financial and economic literacy basics; they do not consider this issue important at preschool age. Thus, the analysis of the questionnaire data showed that only $40 \%$ of parents realize the importance of the economic aspect of raising children. $27 \%$ of parents talk with children on various economic topics, $73 \%$ do not consider this important or find it difficult to answer. Only $27 \%$ of parents talk with their children about the cost of purchased goods. $87 \%$ of parents, when asked whether their children are involved in household work, answered negatively. Most respondents (80\%) believe that economic education should start only from school, $20 \%$ believe that from kindergarten.

To understand the effectiveness of the work, a final diagnosis of the level of knowledge of children was conducted and the second survey of parents after we probed our model of cooperation. The results of the group of pupils showed a high level of financial and economic literacy prevails (73\%), at an average level there are $27 \%$. Comparing the diagnostic results of the group at the first stage (before the model probe) and the third (after the model probe), we obtained the following proportion (Figure 1). 


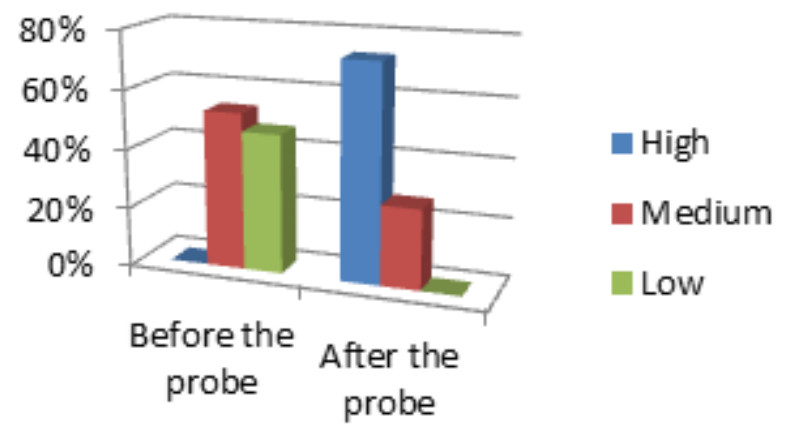

Fig. 1. Comparison of the results of the financial literacy of children before and after the model probe.

The diagram shows that in the group of children the results changed. There are children with a high level of economic knowledge, while at the first stage, an average and low level of development were presented. Children have gained new knowledge, learned to put it into practice, have become more competent in economic development. The survey of parents shows that $40 \%$ of respondents consider the economic aspect to be very important in raising a child. $100 \%$ of respondents explain to children the importance of natural resources and how to save them. $93 \%$ of respondents discuss family budget with children, $100 \%$ of respondents include children in the household. All questionnaires noted that economic education should begin with a kindergarten. As a result of the work, parents began to show more interest in this issue, to pay attention to this work.

\section{Discussion}

A model of work with parents to increase their pedagogical literacy in the economic education of children has been designed and probed (Table 1).

Table 1. A model of work with parents.

\begin{tabular}{|c|c|c|}
\hline № & Activity & Objective \\
\hline 1. & $\begin{array}{l}\text { Parents' conference "Economic } \\
\text { education of children - what is it?" }\end{array}$ & $\begin{array}{l}\text { To introduce the concept of "economic development of children"; } \\
\text { the system of work with children and parents on the subject }\end{array}$ \\
\hline 2. & $\begin{array}{c}\text { Consultation "Needs and } \\
\text { Opportunities of Financial } \\
\text { Literacy" }\end{array}$ & $\begin{array}{c}\text { To draw parents attention to the problem of needs and } \\
\text { opportunities of financial literacy; tell parents about the ways of } \\
\text { interaction with children on this issue }\end{array}$ \\
\hline 3. & Magazine "Save at home" & $\begin{array}{l}\text { To draw parents' attention to ways to save resources at home; draw } \\
\text { parents to work with children }\end{array}$ \\
\hline 4. & "Family budget" models & $\begin{array}{l}\text { To introduce a method of explaining to the child the principles of } \\
\text { making a family budget to parents; involve parents in activities } \\
\text { with children; step up parents }\end{array}$ \\
\hline 5. & $\begin{array}{l}\text { Collection "Money of different } \\
\text { countries and times" }\end{array}$ & $\begin{array}{l}\text { To introduce the methods of explaining to children the value of } \\
\text { money; involve parents in activities; stimulate parents' interest in } \\
\text { the topics presented }\end{array}$ \\
\hline 6. & $\begin{array}{l}\text { Tour to the Nizhny Novgorod Fair, } \\
\text { co-shopping at the supermarket }\end{array}$ & $\begin{array}{l}\text { Talk about available, interesting ways of children's economic } \\
\text { education; making and distribution of the family budget }\end{array}$ \\
\hline 7 & Presentation of professions & $\begin{array}{l}\text { To draw parents to the economic education of children at school; } \\
\text { talk about the diversity of the professional sphere }\end{array}$ \\
\hline 8 & $\begin{array}{c}\text { Discussion "Problems of economic } \\
\text { education" }\end{array}$ & $\begin{array}{l}\text { Support parents in economic education, identify difficulties of } \\
\text { parents in economic education of children; consulting advice }\end{array}$ \\
\hline
\end{tabular}


Work with parents started with a conference, where concepts of "financial literacy" and "economic education" were introduced and discussed. Many parents did not understand why children need economics, because the economy is associated with some kind of global problems and with money. At the conference, issues and problems of children's economic education were concerned, and the need to train in financial literacy and basic economic skills was outlined. Also, recommendations to the parents were formulated to start their work.

Before starting work with children, information on the topic "Resources" was posted in the parent's corner, literature for home reading was offered, which made it possible to simultaneously solve the problem of introducing children to the book, provides information on ways to save resources. To work together, consolidate the material, as well as attract parents to the lives of children, it was proposed to create a magazine "Save at Home". Each family was invited to make an illustration about how they save resources at home, the rules of saving in the family. A series of consultations were held for parents, to tell how to introduce children to the concept of money, the family budget, and how to tell children about the cost of goods. Parents were offered brochures with a list of references on this issue. Parents and children were invited to a tour of the supermarket, to decide what to buy together with a child. Parents and children agreed to this experiment because the children had the opportunity to apply the ideas, to manage the family budget. When studying the family budget, the children, together with their parents, were asked to draw up a model of their budget: what it consists of and where it is spent. Parents were offered excursions to the local sights, market, supermarket with a presentation of a photo story, and children's stories.

The next block in economic education was the introduction to advertising for children. Parents wrote in the questionnaire that children know about advertising, but children see it as a bright picture and stimulus to get what they instantly want. As part of this block, parents were given a series of consultations aimed at explaining to children that not everything that is advertised is necessary and useful. As part of the joint work, parents were asked to create their product with their children and create an advertisement for it, using multimedia didactic means, for example, it was proposed to shoot a video, a story, a poem. As a final event, a discussion was held on "Problems of Economic Education", where parents were able to share their experiences, ask questions, share problems and perspectives.

\section{Conclusion}

Among the wide range of problems associated with preparing children for school, the financial literacy of preschool children occupies a special place, because a person must have business qualities, take an active life position, and be the subject of one's own life. A child from an early age faces such concepts as money, things, labor, value, which is why the problem of economic education has become relevant already to preschool age. In the process of economic upbringing, such personality traits are formed in children as industriousness, thrift, efficiency, equal partnerships in the children's team, self-esteem, the ability to compete honestly and not be afraid of losing, the desire to bring things to the end, a healthy interest in money arises. The rules of their honest earning are learned. The solution to economic problems is carried out in the process of developing cooperation skills, together with labor and moral education.

Modern preschool education practice shows that society demands an economically educated person who can be actively included in modern forms of economic relations. To solve this problem effectively, the interaction of teachers with families of pupils is necessary. In our work, we have proved that with systematic and focused work with parents 
and children on economic education, you can achieve a high, effective, and sustainable result in this trend of education.

\section{References}

1. Bicheva, I. B., Nikolaeva, L. Yu., Stepanenkova, A. V. (2019). Features of the Formation of Financial Literacy in Older Preschool Children. Problems of modern pedagogical education, 64-4, pp. 24-27.

2. Vaganova, O.I., Lapshova, A.V.; Kutepov, M.M., Tatarnitseva, S.N., \& Vezetiu, E.V. (2020). Technologies for Organizing Research Activities of Students at the University AMAZONIA INVESTIGA, 9.369-375.

3. Anoshina, L. M. (2003). Economic Education of Older Preschoolers in the Process of Acquaintance with New Professions. Kindergarten from A to Z, 4, pp. 103-106

4. Shatova, A. D. (2018). Financial Literacy of Preschoolers: Two Sides of the Problem. Preschool education, 2, pp. 22-26.

5. Kozyreva, O. A. (2020). Pedagogical Modeling in the Activities of a Teacher and a Scientific and Pedagogical Worker. Vestnik of Minin University, 8 (2), 1-19. https://doi.org/10.26795/2307-1281-2020-8-2-1

6. Knyshova, L. V., Menshikov, O. I., Popova, T. L. (1996). Economics for Kids, or How Misha Became a Businessman. Moscow: Pedagogy-Press.

7. Kolesova, O. V., Gutsu, E. G., Demeneva, N. N., Kochetova, E. V., Mayasova, T. V. (2020) The Study of Younger Schoolchildren's Reading Literacy at the Present Stage of Education Development. Perspektivy nauki i obrazovania - Perspectives of Science and Education, vol. 44 (2), pp. 240-254. DOI: 10.32744/pse.2020.2.19.

8. Smirnova, Z. V., Vaganova, O. I., Vinnikova, I. S., Lapshova, A. V., Golubeva, O. V. (2020). Modern Multimedia Didactic Tools of Interactive Training. Lecture Notes in Networks and Systems, 73. pp. 485-491.5.

9. Myasishchev, V. N. (1993). The Economics of Education as a Science and a Subject. Pedagogy, 4, pp. 59-64.

10. Kurakov, L. P. (2010). Economic Education and Upbringing of Schoolchildren. Moscow: Education.

11. Zhuykova, T. P., Kokukhina, A. A. (2016). Theoretical Approaches in Economic Education. Problems and Prospects for the Development of Education: Materials of the VIII Intern. Scientific. Conf. (February 2016). Krasnodar: Novatsiya. pp. 108-111.

12. Khanova, T. G., Prokofieva, N. M. (2018). Economic Education in Preschool Age. State Advisor, 1, pp. 25-30.

13. Sasova, I. A. (2019). How to Study Economics for Preschool children? Kindergarten from A to Z, 1, pp. 12 - 14.

14. Galkina, L. N. (2010). The Development of Economic Abilities in Children of Preschool Age. Gifted child, 4, pp. 42.

15. Shatova, A. D. (2013). Prerequisites for the Economic Education of Preschoolers. Preschooler. Methodology and practice of education and training, 5, pp. 4-10.

16. Prokofieva, N. M., Khanova, T. G. (2018). The Need for Economic Education of Preschool Children. Kindergarten from A to Z, 2 (92), pp. 34-40. 
17. Kurbatova, A.S., Bicheva, I.B., Ivanova, N.V., Zaitseva, S.A., \& Krasilnikova, L.V. (2020). Career Guidance Problem as a Systemic Problem in Russian Society. REVISTA INCLUSIONES, 7. 158-173.

18. Vaganova, O.I., Rudenko, I.V., Lapshova, A.V., Bulaeva, M.N., Popkova, A.A. (2020). Psychological and Pedagogical Foundations for Interaction Technologies Implementation at the University AMAZONIA INVESTIGA, Volume 9, Issue 25, pp. 362-368.

19. Yashkova, E.V., Sineva, N.L., Semenov, S.V., Kuryleva, O.I., Egorova, A.O. (2020). The Impact of Digital Technologies on Various Activity Spheres and Social Development. Lecture Notes in Networks and Systems. 91. 149-155.

20. Burina, E. A., Kudinova, A. E. (2020). Modern Russian Family in the Context of Socio-Historical Changes of Parenthood. Vestnik of Minin University, 8-1, pp. 6. DOI: 10.26795/2307-1281-2020-8-1-6. 